\title{
The Malvinas Conflict: Some Elements for an Analysis of the Argentinian Military Regime's Decision-making Process $(1976-1983)$
}

\author{
By Carlos J. Moneta
}

\section{Introduction}

The purpose of this paper is to present some reflections on the decision-making process of the Argentinian military government in relations to the South Atlantic conflict which may serve as a contribution to a more exhaustive study in the future, providing that the corresponding information is accesible. The aim at this time, therefore, is to organize certain elements around a conceptual point of reference, without attempting to deal with the subject in a more systematic fashion.

It is of importance to analyse the decision-making process of the military regime in this case, since, in addition to the opportunity this provides for the application of theoretical instruments related to the consideration of internal factors in the formulation and implementation of foreign policy, it also involves recognition of the impact of the Malvinas conflict on the national and international scene. ${ }^{1}$

As far as the investigation is concerned, the main obstacle lies in the obtention of reliable information for the reconstruction of the decision-making process. When the main body of the paper was prepared (June-July, 1982), a large part of the necessary date was still unknown.

These deficiencies were remedied, as far as possible, by the use of information obtained by the author in personal interviews with high ranking officers of the Armed Forces, politicians, diplomats, mass media people with direct access to the scene of action and government officials. In view of the foregoing, the paper only partially covers the subject, and it is of a provisional nature.

1 The conflict between the United Kingdom and Argentina embraces not only the Malvinas Island, but also the Georgias and South Sandwich Archipielagos. for reasons of brevity, the term "Malvinas Islands" will used in the text, on most occasions.

Part of an article published is issued No 60 (October-December 1982) of the magazine Estudios Internacionales, of the University of Chile, was a study by the author into some of the internal and external factors. The author also published an article concerning the effects on Argentina's possible medium-term political evolution and the impact of the conflict on Latin America's armed forces, in the first 1983 issue of the magazine Foro Internacional, of the Colegio de Mexico.

The details of the process and conflict of the Malvinas (with special reference to the hostilities and international negotiation) can be found in Malvinas: La Historia oficial de la Guerra, Latin American Newsletter, London, 1983. 


\section{Approach and theoretical elements}

For this paper it was considered advisable to use the theoretical approaches based on the role of internal factors in the formulation and implementation of foreign policy.

At the "micro" level of analysis, ${ }^{2}$ naturally the influences inside the State-nation are considered to be important in the formulation and implementation of foreign policy. With regard to contributions to the "micro" level approaches, the two main sources are the theoreticians of behavioural sciences and the experience acquired by the academicians who come and go in government offices (the in-and-outers) and who subsequently give a realistic account of the governmental process. ${ }^{3}$ In view of the author's familitarity with the cosmovisions and the internal decision-making process of the armed forces, and bearing in mind his periods of activity in various sectors of bureaucracy logically he has depended more on the second source, and his experience in that area have led him to make an eclectic use (perhaps a disorderly one) of different theoretical approaches based on internal variables.

As one Latin American specialist rightly pointed out, ${ }^{4}$ those approaches which focus on internal variables elude a clear and well defined classification. The variables tend to overlap and intermingle, the only means of distinguishing between them being often mere degrees of emphasis or nuances which give a highly subjective content to the classification. In principle, they can be divided into four major groups: orientation of the regime; decision-making process and internal policy; bureaucratic policy, and leadership. ${ }^{5}$

However, these approaches are considered to be insufficient to adequately encompass all aspects of the decision-making process. It would therefore appear to be necessary to take into account the orientation of the regime and the close connections between the decision-making process and internal policy.

As for the approaches favouring external variables, note should be taken of the use of the "power policy" approach, with its idea of the State as a rational and unified actor, which emphasizes the use of force as an instrument to satisfy interests in different fields. ${ }^{6}$ This becomes the paradigm of the military leaders who made the decision to occupy the Malvinas.

2 J. David Singer "The Level of Analysis Problem in International Relations" in Klaus Knorr and Sidney Verba, eds., The International System: Theoretical Essays, Princeton, Princeton University Press, 1961, pp. 77-79.

3 See Bradford Westerfield, "Aproximaciones al estudio de la toma de decisiones de política exterior en Estados Unidos", Estados Unidos. Perspectiva Latinoamericana, No 10 (México, CIDE, 2nd half of 1981), p. 19.

4 Alberto Van Klaveren, "El análisis de las políticas Exteriores latinoamericanas: enfoques comparativos (Viña del Mar, Chile, Instituto de Estudios Internacionales, Universidad de Chile and Institute of Latin American Studies, University of North Carolina, 20-23 September, 1982) pp. 23-24.

5 See the above-cited article by Van Klaveren for and explanation of these approaches.

6 See Bradford Westerfield, "Aproximaciones al estudio de la toma de decisiones", op. cit. p. 17 and Robert $O$. Koehane and Joseph Nye, Power and Interdependence: World Politics in Transition (Boston, Little Brown, 1977), pp. 30-31. 


\section{Organization of the paper}

For the purpose of this paper, and in view of its limitations, it is assumed that the main fact relating to the conflict connected with the attempt to recover the Malvinas are known. Consequently, reference will be made to partial aspects or issues involved in said conflict, when this is deemed necessary for a better understanding of the decision-making process of the military regime.

This decision-making process takes place within an alliance of social forces and a political and social structure which differ greatly from the democratic government elected in 1973 and overthrown in March, 1976. The "national project" which was attempted following the military coup is based on a different concept of Argentinian "national interest". This implies substantive changes in Argentina's position vis-a-vis the rest of the world, based on cosmovisions and dominant values different from those prevailing in the previous period. It is necessary, therefore, to bear in mind the orientation of the regime and the impact of certain forms of political organization, as also the development model imposed.

It is in this context that any eventual changes in the actors, the relevant processes for the formulation and implementation of foreign policy, the channels used and the interests at stake will be studied.

\section{Political Regimes and Forms of Insertion in the International System}

The nineteen seventies and the beginning of the eighties witnessed two successive projects - distinct in nature - for Argentina's insertion in the international system: a) that of 1973 to 1976, under successive Peronist presidencies, and b) the so-called "Process of National Re-organization", following the military coup of March, 1976. Under the command of different generals (Videla, Vuloa, Galtieri, Nicolaides) this regime was in power when the Malvinas events occured in April, 1982. The characteristics of both models reveal the lines of continuity and the points of discontinuity in their foreign policy, and this is the context within which the particular policies relating to the Malvinas are to be considered.

\section{The Peronist Project}

The Peronist administrations places emphasis (to a greater or lesser degree, depending on the specific cases studied) on a project of insertion in the international system which sought to achieve greater independence in decision-making and greater autonomy of action, by means of closer and permanent ties with Latin America; the maintenance of a more distant attitute and, at times, one of manifest opposition vis-a-vis the United States, and the establishment and intensification of co-operative relations with the developing countries. Nevertheless, following a line of basic continuity of Argentinian foreign policy, they attach great importance to cultural, political and economic links 
with Western Europe, usually as a manner of compensating for the attitudes assumed vis-a-vis the United States. This, however, did not usually imply any yielding to England in the case of the Malvinas. The peronist political project sought to transfer the populist characteristics of internal social reform, which are one of its features, to the broader community of the international system. World re-organization (which includes satisfying the interests of the developing countries in all areas) must be evolutionary, avoiding as far as possible the use of violence. In its application, the project claims to be pragmatic and adaptable to the changes occurring within the external framework.

Within this context, and bearing in mind its direct connection with other critical problems (Beagle, the Antarctic), the restitution of the Malvinas required a significant enhancement of bargaining power with England, based on over-all growth for Argentina; the greatest possible legitimacy for the recognition of Argentina's rights to the islands and limitation of any eventual support which London might receive from the great industrial powers of the West. For purpose of negotiations, an eventual exhibition of elements of force was envisaged, but not its direct use on a large scale as a preventive measure.

\section{The Economic, Political and Strategic Model of the "Process of National Re-organi- zation (1976-1982)}

\section{General Profile of the Project}

When the armed forces took over in March, 1976, a political, economic and social model was launched, which claimed to achieve a profound transformation of the Argentinian society and its situation vis-a-vis the rest of the world.

The economic project attempts to re-organize the economic and social sector as a whole, in such fashion as to adapt the process of capital accumulation to what it understands to be a more efficient utilization of comparative advantages, with a view to maximizing its possibilities of insertion in the international capitalist system. This implies the intention to consolidate the agricultural sector and certain financial and industrial groups of national origin. ${ }^{7}$

For this purpose it enjoys the decided support of the Armed Forces, in which there was at the time a predominance of top rank officers of liberal tendencies, and the support of international financial capital. In its first stage, the national and multinational industrial groups collaborated with the project, but in view of the progressive dismantling of the industrial apparatus, the absence of the promised growth of the selected sectors and the

7 See, interalia, Ricardo Sidicaro "Argentine: la longue crise du gouvernement militaire", Etudes, Paris, June 1982 and Raul Green, "Argentine 1976-1981, Croissance et décadence d'un projet: le capital national dans le processus économique", CETRAL, Document de Travail No 3, París, 1982, p. 11. 
loss of the benefits initially received by the agricultural sector, the support was confined to groups of the local and international financial and import trade sector. ${ }^{8}$

One essential aspect of the model, which claimed to exploit the comparative advantages of the agricultural sector, was the creation and development of an important local financial market, closely connected with international financial capital. In order that it be economically viable, the project required necessarily the endorsement and co-operation of the traditional Argentinian export poles ${ }^{9}$ - Western Europe and the United States - and that of international financial centres, particularly New York and London. The foreign economic policy had, therefore, to contribute to meeting these requirements, determining conditions - a fact which was to influence the manner in which other matters of foreign policy were dealt with, among others, the case of the Malvinas. With regard to the development of natural resources, the project implies an abrupt change in the policy concerning the exploitation of hydrocarbons. Up to that time, every effort had been made for the latter to remain, as far as possible, under the monopoly of the State-owned company, Yacimientos Petrolíferos Fiscales (YPF). In following years there was a considerable opening up towards the transnational corporations and towards new national groups engaged in oil and gas exploration and development activities. This led the government to organize a system of "risk contracts" by means of which bidding was instituted for exploration areas covering part of the continental shelf of the Patagonian Atlantic and Tierra de Fuego.

As far as trade is concerned, the project promotes a diversification of markets, in which a privileged place is allotted to the Soviet Union (Argentina's exports to the Soviet Union increased from 5.7 per cent of total exports during the period 1975-1979 to 33.7 per cent in $1981 .{ }^{10}$ However, any type of connection was avoided which might eventually lead, according to military criteria, to potential Soviet penetrations of any kind in Argentina. This pragmatic approach, which apparently overcomes the contradictions arising between the ideological demand and economic requirements is not basically the consequence of a sophisticated exercise in the formulation of foreign policy, but is, to a

8 A presentation of the objectives, policies and strategies of the military regime's economic team may be obtained from: Evaluación Económica de la Argentina. April 1976-December 1980, Rep. Argentina, Ministerio de Economía; "Mensaje de Dr. Martínez de Hoz al concluir su gestión como Ministro de Economía, Información Económica Argentina, M. de Economía, March 1981, No 115; "Política Industrial 1976-1980", Información Económica Argentina, No 114, February 1981.

9 Between 1976 and 1980, Argentine changed the traditional patterns of its foreign trade: - very positive balance with the EEC, extremely negative with the United States and balanced with LAFTA - significantly increasing the importance of hitherto secondary markets (Japan and specially the USSR and Socialist Europe), while increasing its exports to Latin America. This led to a relative loss of importance of the EEC and the United States in its trade.

10 The legal regime for the conclusion of oil exploration contracts with the private sector was established by law 21.278 on "Risk Contracts". In 1978, exploration of marine and some land areas began to be transferred to the private sector. By the beginning of 1981, bids had already taken for 11 land and 7 marine areas, including those of "Magallanes Este", "Tierra del Fuego Este (I)" and "Tierra del Fuego Este (II)". See: "La expansión productiva del petróleo y gas entre 1976 y 1981 ", Información Económica Argentina, Ministerio de Economía, February 1981, No 114. 
large extent, imposed by circumstances (e.g.: high degree of protectionism and loss of traditional markets in Western Europe, etc.). Consequently, this policy gives rise, at times, to significant disagreements within the Armed Forces and with some of the economic and public opinion groups whose support they enjoyed.

With regard to the Malvinas, the fear existed, shared by some of the top ranking officers who bore the responsibility of handling strategic matters, that NATO might attempt to extend its jurisdiction to the South Atlantic, and England might fortify the islands and offer them to that Organization as a suitable base for that purpose. The military leaders would have wished Argentina to be the country which, by obtaining control over the islands, would play an important role in the region's western def ence system, thereby consolidating its prestige and "legitimizing" its possession of these archipelagos. ${ }^{11}$

The aim of this foreign policy project was to achieve an active incorporation into the strategic, economic and political sub-system of the western industrialized countries. Emphasizing its character of "emerging intermediate power", Argentina hoped to modify its position in the international hierarchy. That implied, in general, the need to choose a way to obtain greater power and prestige on the basis of an "automatic alignment" in the field of strategy and a "subordinate link" in the economic sector.

\section{Cosmovisions, Predominant Interests and Values: The External Framework}

The political and strategic orientation of the new model of insertion of Argentina in the world system has been clearly stated at the military summit. The ideology of the defence of the "western and christian world" against that "communist aggression", whilst it reflects continuity of the general orientation maintained by previous military regimes, at this stage, in the cosmovision of the decision-makers, attains levels of singular aberration.

Following a cool period, due to the human rights policy of Carter's government, with the arrival of the Reagan administration, relations with Washington improve rapidly. It is a question of developing close collaboration with the United States in the political-strate-

11 Informe Económico de la Argentina, Ministerio de Economía, Buenos Aires, April 1982.

12 In May 1976, the Argentine magazine "Cuestionario" quoted a senior navy official as follows: "If the Western powers decided to place the South Atlantic under NATO's control, Great Britain would be able to offer the Malvinas as an operational base, thereby consolidating the British presence in the islands. On the contrary, should Argentina forestall any external decision, succeeding in forming a regional defense system with Brazil or with Brazil and South Africa - with the co-operation of the United States, though without its formal participation - the West would take a much more lively interest in the solution of the Argentine-British dispute, and the United States could use its influence to bring about London's recognition of Argentina's rights over the Malvinas. It has already been decided that if the islands are recovered, the National Navy will set up a base there. Of course, should Argentine join a system for the defense of the South Atlantic, that naval base would serve the same purpose, but as an Argentine base, installed on national territory" unofficial translation. cit. Clarin, 2 June 1982, p. 15. 
gic field and secondly with Western Europe (although in this case emphasis is placed on financial, commercial and technological aspects).

The aim is to insert Argentina in the western strategic system and assign it an important role by means of active participation in the North American security system for Latin America, with Central America as a privileged area. ${ }^{13}$ To this must be added, according to this approach, the role which fell naturally to Argentina in the defence of the South Atlantic. This included the intention - long cherished by the Navy and by some superior Army officers - to establish an agreement wich the Republic of South Africa and with countries of the Latin American area of the South Atlantic - the South Atlantic Treaty Organization (SATO) ${ }^{14}$ - for the security ot the oceanic area situated between the southern cones of Africa and Latin America, in view of what is felt to be a process of continuous communist expansion. ${ }^{15}$

Both scenarios concurred with those selected by the Reagan administration, although, as subsequent events were to prove dramatically, the priorities and action decided upon by the United States government for the South Atlantic differed significantly from the evaluation carried out by the Argentinian military regime.

The guiding paradigm offers a bipolar and highly conflictive concept of the distribution and competition for power on a world scale. It maintains concepts, criteria and processes which date back to the fifties, to the period of the Cold War, carrying with them an overwhelming load of ideological schematism.

Only some of the main changes which had occurred in the configuration of the international system of the last three decades were incorporated into this approach - and incomplete at that. Such is the case of the economic consequences - detrimental to the developing countries - of the transformation of the productive, trade and financial

13 On this subject, see Luis Maira, "La política latinaomericana de la Administración Reagan: del descurso armonioso a las primeras dificultades" and Carlos J. Moneta, "El papel de los Estados Unidos en la década del 80 en las relaciones entre América Latina y Africa Negra: factores político-estratégicos" in, La Política internacional de los años 80. Una perspectiva latinoamericana, Helio Jaguaribe, Comp., Editorial de Belgrano, Buenos Aires, 1982.

14 See, Carlos J. Moneta "Aspectos conflictivos de las relaciones Afro-latinoamericanas: las vinculaciones políticas, económicas y militares de la República Sudafricana con los países del Atlántico Sur latinoamericano" in C. J. Moneta, Compilador, Geopolítica y Política del Poder en el Atlántico Sur, Editorial Pleamar, Buenos Aires, 1983, pp. 130-137.

15 SATO has not materialized to date due to various factors (eg. Brasil's political rejection of the idea; the Argentine-Chilean Beagle dispute; the need to formally break ties with the South African Republic in order to obtain Black Africa's support in the Malvinas Conflict., etc.). Nevertheless, the geopolitical viewpoint based on the anti-communist mold has not changed in the high ranks of the Armed Forces. For instance, Vice-Admiral Luis María Mendía stated at the end of the first quarter of 1982: - "Communism sensed the importance of the "strategic circle" un of ficial translation represented by Africa, which process is continuing. It attempted to capture the Southern Cone of America by means of subversive warfare, but without success. Should the communist expansion manage to gain control over the South Atlantic, this would create a critical situation for Western Europe and the United States, "the heart of the West" unofficial translation. See "El Atlántico Sur", in Futurables, publication of the Fundacion Argentina Año 2000, Buenos Aires, No 13, 1 st. quarter of 1982, p. 59. 
structure and the phenomena of worldwide transnationalization. This gives rise to an Argentinian position which criticizes the concentration of benefits in the group of industrialized powers. Likewise, there is an awareness of greater possibilities in some fields and for some of the Third World countries for the implementation and maintenance, in the face of the pressure exerted by more powerful actors, of autonomous policies of a sectoral and limited nature (e. g. nuclear development; trade with the Soviet block).

In the conceptual view of the decision-makers, this inclusion of heterodox elements is not prejudicial to the central ideological axis to which they adhere (the struggle between "good" and "evil" represented by the East-West confrontation), but applies the rules of the game, of the system in force, in terms of their own interests.

Within the context of this ideological discourse the course of foreign policy becomes intelligible. Thus, for example, it is apparently possible to reconcile: a) an active, although moderate defence of certain Third World principles and reclamations with respect to the New International Economic Order; b) the firm intention of the military leaders, during the greater part of the period, to break away from the group of non-aligned countries; $c$ ) the rejection of the idea of considering Argentina conceptually as a Third World country and; d) the enthusiastic and open participation of military advisors, the supply of war material and financing in the internal conflicts of Central America, aimed at destabilizing the new revolutionary governments and supporting the authoritarian and repressive regimes.

The inflexibility of the ideological concepts prevailing, which are the result of and internationalization of the thesis of the "inside enemy" and of the inculcation, through the doctrine of the North American Armed Forces, of the importance of the campaign against the Soviet Union, is accompanied by a provincial view of world events and a notably distorted idea of the country's own capacity. Part of these characteristics are due to the remonteness of the power centres, the country's relative marginality vis-a-vis the latter and, to a large extent, to the deficient cultural and political background and low degree of socialization of the majority of the officers of the Armed Forces.

In the field of international politics, the Armed Forces combine values of the neo-liberal system - basically the economic component - with elements of military culture: their dependence on the more developed western countries for reasons of prestige, of values, doctrinary bodies and technical factors (arms).

Being subjected to a permanent and effective exercise of transfer of values and ideological concepts from the United States, through indoctrination in the different schools and courses, joint military excercises, mutual visits between Forces, etc., the Argentinian military have, to a large extent, internalized the paradigms of their North American peers, favouring the East-West conflict, as a central conflict, and consequently belittling the importance (but not in all cases) of the North-South conflict.

Another reason, according to a North American military leader and political scientist, is that in the absence of real and serious external dangers, the military actor usually tends 
to universalize the Comunist threat to the "western and christian world" and seeks a role for his country in opposing said threat. ${ }^{16}$

On the other hand, there is the hope that a distinguished role will be assigned to the Forces themselves in the alliance, and that military advantages will supposedly be obtained in the form of modern weapons, of that certain political favours will be forthcoming (e. g. United States "support" for recovery of the Malvinas). It is hoped thus to improve the relative situation of the country in the regional balance of power and/or vis-a-vis potential subregional antagonists, to achieve some objective considered by the military to be of "national interest". These factors contribute to the colder determination, in terms of costs and benefits, of this type of alignment.

\section{Cosmovisions, Predominant Values and Interests in the Internal Framework}

Based on their function in society - that of acting as an element of cohesion from the internal point of view, and from the external point of view as and armed body to protect it-the real role of the Armed Forces depends, to a large extent, on the cosmovisions within which their thinking is framed and the interested which guide their action. In the case of Argentina, the political process can be understood as competition between different social groups for the control of political and economic resources, without reaching the point of forming a block of alliances capable of completely imposing their hegemony. Up to the middle of 1966 (Gen. Onganía's coup) the military, at critical moments, performed the function of temporarily imposing hegemonies, taking authoritarian measures to assemble the social groups around some type of national project. ${ }^{17}$ The idea was to restrict (or exclude) political and economic participation of the groups which were considered to be "dangerous", protecting the interests of the dominant minority segment. Once order was re-established and the threatening sectors had been "controlled ", the Armed Forces returned to their barracks. ${ }^{18}$

These attempts a t stabilization are made within a social context in which the competition between the different groups for the distribution of resources is seen as "the sum equal to zero". Furthermore, the society sets its own precepts for political action, which overrule the existing norms, e. g. - "if I don't get what I want, I break the rules of the game, that is to say the institutional order" - (e. g. temporary alliances between the Armed Forces and the trade union sector, excluding the political parties, etc.).

The growing participation of the Armed Forces in the exercise of gouvernment through authoritarian-regimes gave rise, among other things, to a significant increase in their

16 Charles D. Corbett, The Latin American Military as a sociopolitical force. Case study of Bolivia and Argentine, Monographs in International Affairs, Center for Advanced International Studies, University of Miami, 1972, pg. 13.

17 Roberto Russell and Teresa Carballal, "Democracia y autoritarismo en Argentina: los problemas estructurales del sistema político y su incidencia en la redemocratización" (Preliminary version), Seminario sobre Sistema Politico y Redemocratización. Viña del Mar, Chile, 1983.

18 Ibid. 
influence and political weight in society; the gradual internalization of geopolitical thought in the civil society; a dramatic reduction of the space available for political interaction in accordance with democratic rules (b) and an increase in the interest and autonomy of the Armed Forces within the State, which allows them to gradualy develop their own political project.

With the coup known as the "Argentine Revolution" (1966-1973) a different stage begins as regards the role which the Armed Forces assign to themselves in society. The change - which is tremendously intensified during the process of National Reorganization" (1976-1983) - consists of the replacement of the role of "agent of arbitration" between different social groups by that of "agent of transformation" of society.

Thus, the so-called "Process of National Reorganization" which began with the overthrow of Isabel Martínez de Perón, presents distinctive characteristics, since it is no longer simply a question of ensuring the power of the predominant economic segment by means of a substitute hegemony, but, unlike previous coups, the military actor fuely develops his own project, which is shared by the most transnationalized financial and entrepreneurial sectors.

The aim of overthrowing the constitutional government, on March 24, 1976, was to eliminate the predominance of peronism and of the trade union sector in the political sphere, in addition to eliminating the radical left-wing groups. The purpose was to solve the problems of an "inefficient" democracy, ${ }^{19}$ advancing - "without deadlines" - towards a hierarchical, orderly democracy, free of "marxist subversion" and uncontrolled "peronist demagogical populism".

As one of the military ideologists stated, the cause of the coup is not the need to battle against the guerilla, since...-"there was nothing to prevent eliminating subversion under a constitutional government. In March, 1976, the Armed Forces overthrew a government which was submerged in its own chaos, its corruption and its absolute inability to govern the country from the political, economic and social point of view ... The justification of the taking over of power by the armed forces in 1976 was to close a historical cycle, as was stated even in the text of certain laws" $-\ldots{ }^{20}$ Thus - "the Armed Forced restored the nation's security and recovered their role as bastion of the Republic". ${ }^{21}$

The idea was (supposedly definitely this time) to get out of the impasse and impose a model which would place Argentina in a position consonant with the new situation of word capitalism, through an economic reinsertion of Argentina enabling it to exploit its comparative advantages as an agricultural and livestock exporter and also, in the future, an energy exporter, ${ }^{22}$ and to finally join sides, in the strategic field, with the forces which

19 Ibid.

20 General Ramón G. Díaz Bessone, "Sentido y justificación de las Fuerzas Armadas en el gobierno", Editorial by the magazine Futurables, No 13, Fundación Argentina del Año 2000, Buenos Aires, first quarter of 1982, pp. 8-9.

21 Ibid.

22 Carlos J. Moneta, "El factor energético en la política internacional de América Latina", Gaceta Internacional, Year 1, No 2, Caracas, octubre-diciembre 1983. 
were battling against "international marxism", since - "the war between the free world and marxism headed by Moscow, is also fought on the battlefield of our continent $"{ }^{23}$

\section{Internal factors}

The main internal factors are: a) the transfer of priority from the Beagle case to that of the Malvinas; b) the rapid and acute deterioration of the internal political-economic situation and; c) the possibility of using the Malvians as a heroic feat which would legitimate the military regime, purging it of its repressive policy, the violation of human rights, the acts of corruption committed and the serious economic deterioration resulting from its administration.

With regard to the modification in the situation of the conflict which would probably have to be settled by warlike means, several elements influenced the military assessment: the possibility of the presence of Chile in the South Atlantic - and an eventual closer link with England - in the event of a settlement unfavourable to Argentina in the Beagle dispute, in the first place; the fear that London might grant some form of autonomy to the inhabitants of the Malvinas of negotiate with the United States the establishment of military bases in those islands. ${ }^{24}$

The manifestations against the regime during the weeks prior to the invasion and particularly the strike of March 30, cause a sudden loss of political space for the gouvernment, rapidly increasing its vulnerability in a context of serious economic crisis and social unrest. This appears to have been one of the factors which most influenced the decision to invade immediately, since everything leads one to assume that the decision to invade the islands some time between August and October, 1982 had already been adopted between December and February of that year. ${ }^{25}$

Finally, one element pointing to suggestive links between a segment of the military summit and the crucial decision to recover the Malvinas emerges with the identification of those superior officers who took the most active part and assumed leadership in the operation. If is precisely those leaders of the Armes Forces - including the president himself - to whom the reports of Amnesty International and other sources refer as military people deeply involved in the process of the "war against internal subversion", the outcome of which was the death and disapperarance of over 20000 people, who played the main roles in the decision-making process and commanded the Malvinas operation.

These military leaders were deeply concerned by the possibility of a transfer of power to

23 Gral. Genaro Díaz Bessone, "La seguridad y la libertad del continente", Futurables, No 13, pub. cit., p. 13.

24 See statements by the Head of Foreign Minister Costa Mendes' Executive Office, Amb. Gustavo Figueroa, IPS Cable, 24 May 1982, "Estados Unidos quiere base anglo-norteamericana en las Malvinas, dice diplomático".

25 The date of which the decision was taken to invade in 1982 is based on talks with top leaders of the Armed Forces. Various sources and researches including English and North American sources, coincide on this initial evaluation. 
the civil society, which would lead to investigations and trials and which might reveal their responsibility in the repressive measures. The intention of the military to "compensate" for their previous behaviour in the government by recovering territories which constitute a national objective fully shared by the Argentinian society, clearly emerges from the public declarations made by high-ranking officers of the Armed Forces. Some of them are of the opinion that it would even be possible to recover the political control of the process and channel it towards and electoral solution suitable to its ends. General Galtieri himself recognized in a newspaper report published after the defeat of the Argentinian forces, that wif everything had gone as planned, Galtieri's idea was to call for gradual elections: Parliament and Presidency of the Nation, for which he would habe posed his candidature with the certainty of an easy triumph . . ${ }^{26}$

\section{External factors}

There is already evidence that the Argentinian military leaders were very mistaken in their "assessment of the situation" with respect to three essential aspects: 1) the reaction of the United States; 2) the reaction of England; and 3) the support to be expected from the world community in international fora.

\section{1) and 2) The reactions of England and the United States}

The President himself, General Galtieri, publicly achnowledged ${ }^{27}$ that a military reaction was not expected from the English, and, in the event of such a reaction, it was expected to be extremely moderate and destined rather to reinforce London's negotiation strategy. The military strategists were even less able to foresee the stand that the United States was finally to take in favour of England. ${ }^{28}$

In addition to an obvious elementary ignorance of the relative weight of the United Kingdom and Argentina in Washington's global plan of strategic alliances, and of the depth of the cultural, political, ideological and economic links with England, two types of factors seem to have contributed to the mistakes of the military leaders in their

26 Carlos J. Moneta, "El conflicto de las Malvinas: algunos elementos ..." op. cit. For Gen. Galtieri's declaration see Nestor J. Montenegro and Eduardo Aliverti, Los Nombres de la Derrota Ediciones Nemont, Buenos Aires, 1982, p. 23.

27 President Galtieri: "I cannot tell you that although it was considered that Great Britain would possibly react, we did not believe that a mobilization was probable over the Malvinas... In my opinion, it was hardly possible and totally improbable.

28 In any case, I never expected such a violent reaction, no-one did " Unofficial translation. With regard to the United States: "I must say that I bear it an enormous grudge, as the American know very well that as Commander of the Army, that is, before becoming President, I always sought rapprochement with them and their administration, to renew the mutual understanding which had lost strength under the previous administration ... it was very disappointing when (Haig) took the part of the English . . the worst is that Reagan and his staff did the same. The truth is that the Argentines share my opionion that this is a betrayal" Unofficial Translation. "Galtieri. Argentina seguirá combatiendo", El Nacional, Caracas, 16 June 1982, p. A-8. 
estimation of the probable North American response: a) the situation of "privileged friendship" with the Reagan Administration, as seen by the military regime, and b) the previous feelers which had been put out with said Administration.

The first interpretation is based on what was considered to be an enormous contribution made by Argentina to the United States in Central America, in keeping with the strategy of contention of the revolutionary governments of the area as defined by the North American Administration. Although there are no precise data on the subject, the reports obtained in Buenos Aires, the United States and Central America suggest that the participation of the military and paramilitary was significantly greater than that indicated in the international press, both as regards the number of participants and the variety of actions undertaken by them.

On the other hand, the "surprise" of the military government at what it considered to be a "betrayal" on the part of the United States government appears to be the result of: a) assumptions: implicit commitments contracted by the United States vis-a-vis the regime, in exchange of the collaboration provided by the latter in Central America and on obligations stemming from TIAR; ${ }^{29}$ b) contacts and conversations which might have referred to these matters indirectly and which took place with eminent highranking military and civilian personages in the Reagan administration, among others, Ambassador Kirkpatrick and the Under Secretary for Latin American Affairs, T. Enders. It is a fact, for example that with the exception of a limited group of congressmen, there were practically no deelers put out or approaches made to the Legislature. On the other hand, a large number of the contacts made by the Argentinian military diplomats in Washington were with persons belonging to the so-called "South African lobby" ${ }^{30}$ whilst criticizing apartheid in the United Nations; defence of the principle of non-intervention and active participation in the internal conflicts of Nicaragua, El Salvador and Bolivia did not precisely help to attract the sympathy of Africa and Asia in the group of Non-aligned countries and in the United Nations agencies. It also hampered - together with other factors - the evolution of the degree and type of support received in the OAS. Furthermore, the intervention in Central America of military advisors, specialized in

29 Former President Galtieri maintains: "I acknowledge that we assumed that the United States, as an OAS Member, as a signatory to TIAR, as an American state, would certainly not turn its back on us. We believed that its ties with Latin America would gain in importance alongside those linking it to an extra-continental ally. Obviously, we were wrong", Unofficial translation Los Nombres de la Derrota, op. cit., pp. 24-25.

30 By way of example: A Seminar washeld in December 1981 in Buenos Aires at the "Fundación Argentina Año 2000", under the guidance of Gen. R. Díaz Bessone and attended by some Republican Congressmen: Skeen, Rep. of New Mexico; Nelligan, Rep. of Pennsylvania; Mrs. Carlist, Chaiperson of the Senate Republican Committee; J. Lisker, Chairman of the Senate Subcommittee on Security and Terrorism; Profesors Lewis Tamb and Thomas Ward, specialist in Geopolitics and the General of the United States Marine Corps, Lewis Walt. The Seminar was entitled "The Security and Freedom of the Continent "* and its principal themes were "the West's weakness"*, "The situation in Central America and the Caribbean"* and, with special prominence, "The strategic importance of the South Atlantic ". *General Díaz Bessone, former Minister of Planning of Gen. Videla' government and personal friend of President Galtieri, was the organizer of this Symposium. (* Unofficial translation.) 
subversive warfare, which was common knowledge almost immediately throughaut Latin America, the United States and Europe, with the exception of Argentina itself, was a factor which appears to have borne its weight in the Soviet Union's decision not to commit its vote in the Security Council. ${ }^{33}$

\section{Attitudes and positions adopted by the political leaders}

This subject, in view of its complexity and importance, warrants an in-depth and exhaustive analysis. However, it is of interest to note here certain elements, in view of their effects on the interactions between the "civil society" and the "military actor". In February, 1982, a co-ordinating mechanism of the political parties, called the "Multipartidaria", published a project for Argentina based on an agreement on national objectives and policies. With reference to the Islands, "the immediate restitution of the Malvinas" was demanded.

According to the information available, the political leaders had no previous information of the decision to recover the islands by force of arms. They were officially informed of this a meeting with the Minister of the Interrior when the Malvinas were already under control.

In general terms, the Armed Forces enjoyed the support of the political leaders. With the exception of severe criticism from the "Movimento de Integración y Desarrollo" (MID), some personages of the centre-right parties, a limited number of Peronist trade union leaders and the "Intransigencia" sector of said party, the party leaders at first not only gave their tacit consent but also their active collaboration.

This took the form of missions abroad, undertaken by eminent political figures, to gain the support of the Latin American countries for the Argentinian position, and to "explain" to European countries and to the United States the reasons which had led to the military occupation of the islands.

Likewise, the party leaders were invited to the formal establishment of Argentinian authorities in the Malvinas.

The explanation offered by some political leaders with regard to this behaviour was based on two causes: ${ }^{34}$ a) That the recovery of the islands constituted a "national cause"

31 Security Council Resolution 502 (1982) contained three elements: ceasing of hostilities; withdrawal of Argentine forces from the Malvinas Island and the search for a diplomatic solution. As affirmed by the Minister of the Interior, General Saint Jean, in a meeting with political leaders, the veto by the People's Republic of China in the Security Council could be disregarded. Foreign Minister Costa Mendes denied that the veto had been requested from the People' Republic and the USSR prior to 2 April, but indirectly confirmed that the veto had been requested of the USSR. See La Nación, 7 April 1983, p. 16.

32 Examples abound in this matter. Suffice it to cite the editorial "Este-Oeste: Norte-Sur" of the daily $\mathrm{La}$ Prensa, 2nd section, editorial page, 5 June 1982, the daily La Nación also maintained basically this position throughout most of the conflict.

33 Ricardo Kirschbaum, "Los riesgos de la diplomacia doble", CLARIN Buenos Aires, 11 november 1982, pp. 14-15.

34 Talks held with Argentinian political leaders, members of the "Multipartidaria". 
and as such, the action taken by the regime deserved support; $b$ ) that if said support were not forthcoming, the political parties would lose face vis-a-vis their respective clients, since the latter had spontaneously and categorically approved the occupation of the Malvinas (although that did not mean they approved the military regime's actions in the other problem areas: disappearance, economic crisis, corruption, etc.).

To put it shortly, the politicians estimated that if they opposed or refused to collaborate, they would lose their leadership capacity and prepare the ground for the support of the "military party" by the masses. Finally, there appears to have been confidence in the military's ability to retain the islands or to successfully negotiate their restitution by England.

The support initially given to the military operation decreased as the moment of defeat approached, whilst there was a withdrawal from the official positions and a gradual increase in criticism (e.g. the sector of the Union Civico Radical) headed by Alfonsín; MIR, the Peronist "Intransigencia" group).

Bearing in mind the foregoing, it can be said that:

1. The decision to carry out the Malvinas military operation was adopted at the military summit, and had been kept secret ${ }^{35}$ with no participation or consultation with the representatives of the political parties.

2. The party leaders were informed later, when their collaboration was sought since it was a question of a "a patriotic cause". The purpose of formal their official participation (presence in official events; sendings of politicians to special mission in other countries, etc.) was to legitimate the military regime's action, both within the internal framework and abroad.

3. The attitude adopted by the party leaders appears to have been based on: a) The fact of sharing certain objectives with the military, such as that of the recovery of the Malvinas, since this constitutes a national cause; b) The belief that it was necessary to present a united front and not manifest internal dissent at a time when the country was facing a critical international situation; c) An egoistic calculation suggesting that it was better not to contradict the support offered by the majority, in order to avoid the risk of losing their own positions as leaders.

The attitude of the civilian leaders indicates the inability of the political class to respond autonomously in the face of unexpected critical events. Likewise, it reveals their enormous professional limitations, since their attitude is not exactly that of statesmen. To this is added their dramatic lack of knowledge of international affairs since, except for a few very rare cases, not only did they not realize the negative consequences of the decisions being made, but, to a certain extent, they shared the cosmovision of the military leaders.

During the attempts at negotiation to settle the conflict between Argentina and Great Britain, very few politicians raised their voice either to support and demand the adoption of this course of action. Actually, the majority of those who in one way or another

35 Statement by Gen. Galtieri in "Los nombres de la ...", op. cit., pp. 22-22. 
maintained that the conflict should cease were the leaders of the financial and enterpreneurial sectors most closely connected with transnational capital, for the obvious reason that the conflict affected their interests.

Finally, the desire "not to be left out of the game" (even though they were actually playing a marginal role), to keep or gain positions in the short run, drastically limits the realizations of the existing alternatives and tends to supply routine responses (e.g. follow whoever has leadership at the time) to new and complex situations.

\section{Conclusion}

The various elements presented in this paper point out the importance of an in-depth analysis of the following factors:

1) The role played by the cosmovisions, ideological factors and corporative and personal interests in the decision-making process of an authoritarian regime.

2) The particular characteristics of the decision-making mechanism of this type of regime ("shared veto", etc.).

3) The reiterated recourse to an international conflict (prestigious also, in this case, to overcome a critical internal situation), attempting, by this means, to legitimate the military regime.

4) The extent and depth to which the society's political decision-making space is occupied by the Armed Forces under a military regime.

5) The significant reduction of the universe of alternatives which can be identified for the adoption of decisions with this type of regime.

6) The gradual internalization in the civil society of the military actor's cosmovisions and patterns of thought, that is to say, the gradual coercive imposition of a national political sub-culture as the focal point of foreign policy.

7) The differences existing between the behaviour of democratic regimes and that of authoritarian ones in the field of foreign affairs. In this case there are visible modifications with respect to previous civilian regimes as regards: basic understanding (conceptualization of the international system), identification of alternative courses of action, ability to assess the problem within a global context of complex interactions, participating actors, decision circuits, mechanisms of the channelling and resolutions of demands, assignment of priorities to conflictive subjects, etc.

8) The effects on the foreign policy of the modifications of the regime (development model, actors, interactions and relative power of each one) of the "hegemonic block" in that society.

9) Within the context of the aforementioned points, the importance of the intranational process and the possibilities afforded by the application of the bureaucratic policy approach are evident. In this case there is no unitary actor, but a certain number of actors who have to solve or counteract different internal and international problems which are interconnected. Within this framework, the actors do not act according to a consistent series of strategic objectives, but in terms of various concepts of national 
security, personal interests and those of the organizations to which they belong. ${ }^{36}$ The decision-making process does not consist basically of a calm, balanced and rational choice between a set of alternatives, taking all the factors into account but takes the form of an activity which, on the basis of a given situation, usually very confused, considers immediate alternatives ${ }^{37}$ in a process characterized by struggles, oscillations and frequently changing course.

Thus the bureaucratic policy as approach of fers suggestions ${ }^{38}$ which have been proved to materialize in the decision-making process related to the Malvinas. ${ }^{39}$ For example: a) that organizational interests are of ten dominated by the desire to maintain the autonomy of the organization and by the competition for the obtention of certain missions ${ }^{40}$ (e.g. conflicts between the Air Force and Naval Aviation regarding the assignment of responsabilities and strategic tasks and tactics; b) that the majority of the actors adopt a short-term approach; c) that the structure of decisions is such that it is difficult to supervise them and; d) a considerable margin of action is left as regards which subordinates are to be involved and which specific actions are to be adopted;41 e) that the idea of the "national interest" and of the problems and priorities of "national security" involves attitudes, images, and values shared by the actors participating in the decisionmaking process; $f$ ) that many of the participants tend to "interpret" the actions of other nations in such fashion as to adapt them to their previous images, instead of examining the facts objectively.

36 Graham T. Allison y Morton H. Halperin, "Política Burocrática: un paradigmy y algunas implicaciones de política" in La toma de Decisiones hacia Améria Latina, Cuadernos Semestrales. Estados Unidos. Perspectiva Latinoamericana, CIDE, No 10. 2nd Half of 1981, CIDE, México, p. 221.

37 Ibid.

38 Ibid, pp. 235-241-245.

39 To verify these suggestions, see President Galtieri's statements in the report on him, given in the book Los nombres de la Derrota, op. cit., and the "Informe Rattenbach".

40 Graham T. Allison y Morton H. Halperin, "Política Burocrática ...", art. cit.

41 Ibid. 
The Malvinas Conflict: Some Elements for an Analysis of the Argentinian Military Regime's Decision-making Process (1976-1983)

\section{By Carlos J. Moneta}

The purpose of this paper is to present some reflections on the decision-making process of the Argentinian military government in relation to the South Atlantic conflict, which may serve as a contribution to a more exhaustive study in the future. It also involves a recognition of the impact of the Malvinas conflict on the national and international scene.

The paper analyses the characteristics of the political regime in power, its goals, values and the means applied to reshape Argentine society; the concentration of the decisionmaking process in a very limited number of actors, most of whom belong to only one type of organization, namely the armed forces; the exploitation of a national cause - the recovery of the Malvinas - to obtain support and international political legitimacy for the regime which was at that time facing massive serious social and political unrest. It also examines the particular ideologies of the leadership and the problems of competition between them and between their respective organizations.

Special attention is given to the Argentine military leaders' distorted perception of the international system, the East-West confrontation and the ways by which Argentina may improve its strategic stature achieving at the same time an historical goal: To recover part of the national territory under British occupation since the 19th century.

Finally, the paper briefly explores the long-term political impact that the Malvinas war could have upon Argentinian society in a context where it is attempting to restore democracy.

\section{The Political Structure of a Bangladesh Village}

\section{By Dietmar Herbon}

The integration of the rural population into the processes of development, or rather of solving multiple problems, in Bangladesh requires adequate social and political forms of participation.

Knowledge of present conditions and structures is a prerequisite for corresponding concepts and strategies. Based on an empirical investigation, political structures of a Bangladesh village are described and analysed.

Firstly, single positions, criteria and levels of the leadership structure are discussed and the corresponding types of leaders presented.

Secondly, the leader and follower structure of the whole system is shown, including the fact that in the village more than just one "pyramid of leader and follower" exists, and that they form variable coalitions and factions competing with each other. 